\title{
Megacolon tóxico de origen idiopático: cuando no hay mucho que hacer
}

Toxic megacolon of idiopathic origin: when there is no so much to do

Mauricio González-Urquijo ${ }^{1}$

Paciente de sexo masculino de 53 años de edad con antecedente de meningitis bacteriana a los 40 años, con secuelas neurológicas psicomotoras. Antecedente de constipación de 6 días de evolución. A su llegada a urgencias se encontraba en choque séptico, con alteración del estado de alerta, por lo que se decide intubar. A la exploración abdominal se encontraba un abdomen en tabla con resistencia muscular involuntaria. Radiografías muestran asas de colon dilatadas y TC de abdomen se observa abundante material fecal en recto y asas de colon distendidas (Figura 1). Se realiza laparotomía evidenciando la totalidad del colon hasta el tercio inferior del recto, gangrenado, de aspecto verdoso y fétido (Figura 2). Se realiza colectomía total, con ileostomía terminal (Figura 3). El paciente fallece a las $24 \mathrm{~h}$ de haber

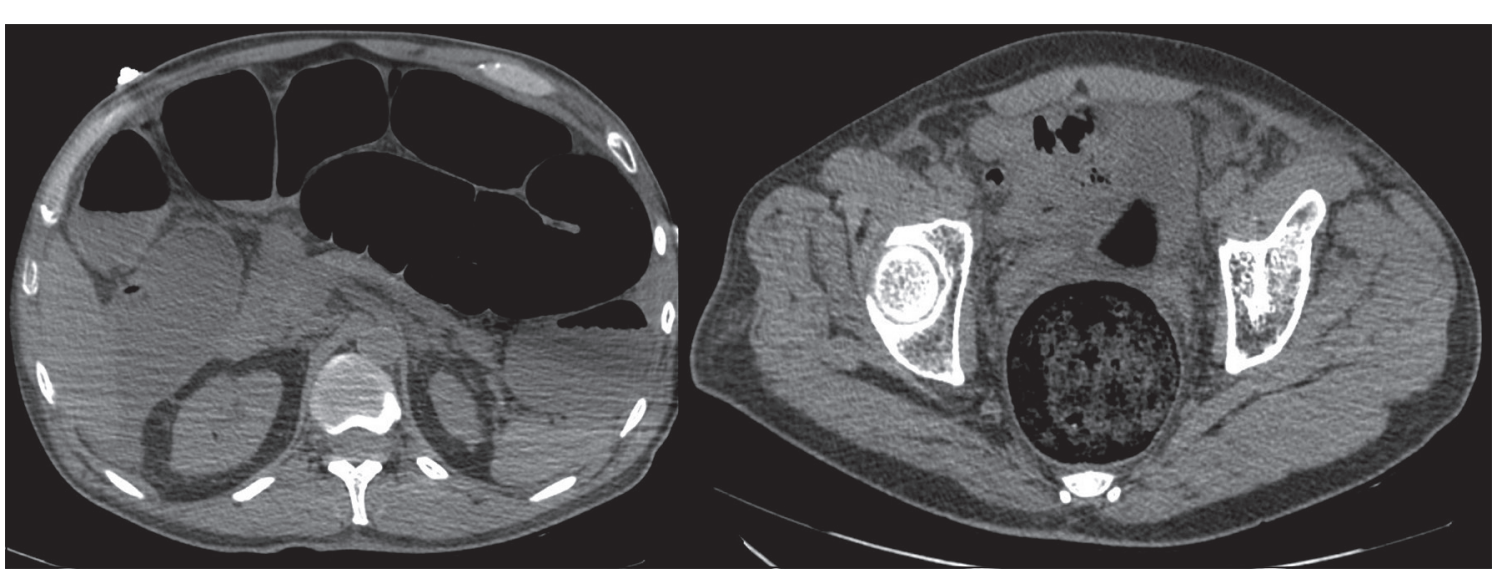

${ }^{1}$ Tecnológico de Monterrey, Escuela de Medicina y Ciencias de la Salud. Dr. Ignacio Morones Prieto O 3000 Monterrey, Nuevo León México.

Recibido el 6 de octubre de 2019 y aceptado para publicación el 14 de octubre de 2019.

\section{Correspondencia a:}

Dr. Mauricio González-Urquijo mauriciogzzu@gmail.com

Figura 1. Cortes axiales de tomografía computada de abdomen y pelvis.
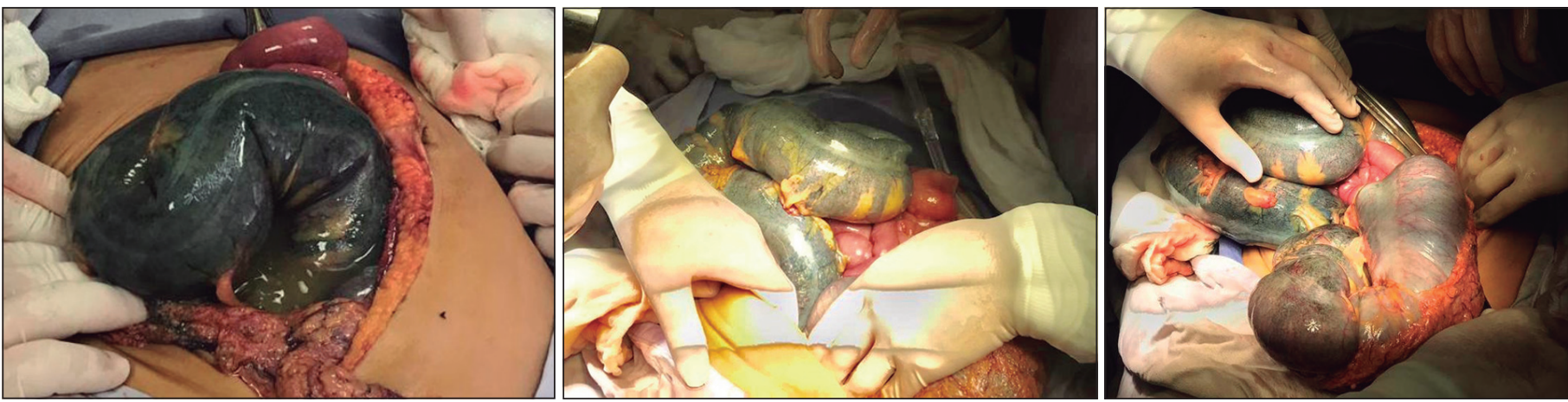

Figura 2. Laparotomía exploradora evidencia colon necrótico. 
Figura 3. Pieza operatoria

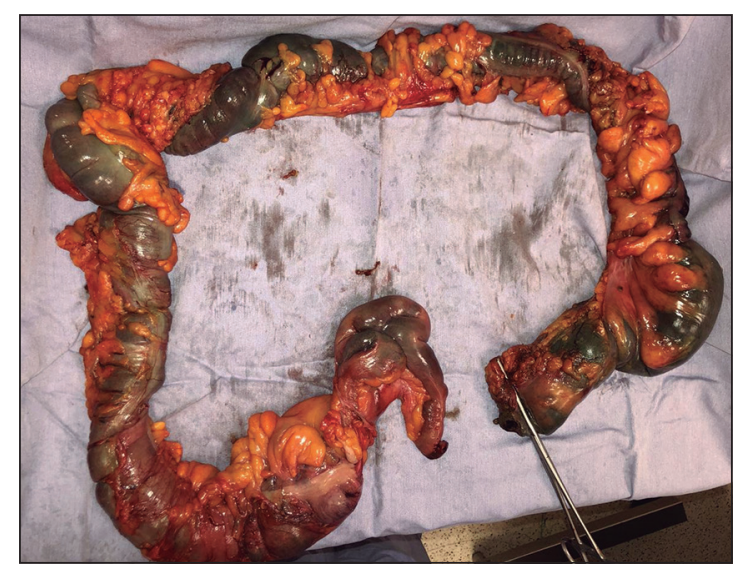

sido intervenido. El resultado de patología mostró únicamente inflamación crónica, descartando alguna otra enfermedad.

El megacolon tóxico (MT) es una dilatación aguda no obstructiva del colon, acompañada de signos de toxicidad sistémica, que aparece como consecuencia de una inflamación grave del colon ${ }^{1-3}$. Es primordial que los pacientes con MT sean diagnosticados rápida y correctamente, para disminuir la morbimortalidad.

\section{Responsabilidades éticas}

Protección de personas y animales. Los autores declaran que para esta investigación no se han realizado experimentos en seres humanos ni en animales.

Confidencialidad de los datos. Los autores declaran que han seguido los protocolos de su centro de trabajo sobre la publicación de datos de pacientes.

Derecho a la privacidad y consentimiento informado. Los autores declaran que en este artículo no aparecen datos de pacientes.

\section{Conflictos de interés: No hay.}

\section{Bibliografía}

1. Siado SA, Jiménez HC, Martínez Montalvo CM. Megacolon toxic of idiophatic origin: Case report. Rev Colomb Gastroenterol. 2018;33:166-71. doi:10.22516/25007440.256

2. Carrillo-Esper R, Calderón-Álvarez Tostado JL, Muciño-Bermejo J, Ramírez-Rosillo FJ. Megacolon tóxico Caso Clínico. Med Interna México 2012;28:282-7.
3. Gan SI, Beck PL. A New Look at Toxic Megacolon: An Update and Review of Incidence, Etiology, Pathogenesis, and Management. Am J Gastroenterol. 2003;98:2363-71. doi:10.1111/j.15720241.2003.07696.x. 